\title{
STUDIES OF THE DISTRIBUTION OF THE MAJOR CATIONS IN SEMEN AND MALE ACCESSORY SECRETIONS
}

\author{
P. J. QUINN, I. G. WHITE AND B. R. WIRRICK \\ Department of Veterinary Physiology, University of Sydney, \\ Sydney, Australia
}

(Received 15th March 1965)

\begin{abstract}
Summary. The atomic absorption spectrophotometer provides a simple and easy method for determining sodium, potassium, calcium and magnesium in whole semen, spermatozoa and seminal plasma.

Analyses of ram, bull, human, dog, rabbit and fowl semen all reveal a reciprocal relation of potassium to sodium in the spermatozoa and seminal plasma. The high potassium and low sodium concentration of the spermatozoa, coupled with a low potassium and high sodium concentration in the seminal plasma, suggest the operation of a sodium pump mechanism in spermatozoa similar to that postulated for erythrocytes. The magnesium concentration of the spermatozoa always exceeded that of the seminal plasma, whilst the same is true for calcium, except in the bull where the seminal plasma has an exceptionally high calcium content.

The distribution of cations between the epididymal spermatozoa and epididymal plasma in the ram and bull is, in general, similar to that between ejaculated spermatozoa and seminal plasma. However, there were substantial differences in absolute values: the sodium concentration of epididymal ram spermatozoa was half that of the ejaculated cells and the potassium concentration about double.
\end{abstract}

\section{INTRODUCTION}

The influence of inorganic cations, such as sodium, potassium, magnesium and calcium, on the motility and metabolism of ram, bull, rabbit, dog and fowl spermatozoa has been extensively studied (Lardy \& Phillips, 1943; White, 1953a, b, c, 1956; Blackshaw, 1953a, b; Wales \& White, 1958a, b; Gragle \& Salisbury, 1957, 1959; Wallace \& Wales, 1964). No systematic studies have, however, been made of the concentration of inorganic cations in the semen of the various species or of their distribution between the seminal fractions. Various workers have reported values, which often conflict, for one or more of these ions in the semen of the ram (Dott \& White, 1964; Mann, 1964), bull (Bernstein, 1933; Rothschild \& Barnes, 1954; Cragle, Salisbury \& Muntz, 1958; Cragle, Salisbury \& VanDemark, 1958), man (Huggins, Scott \& Heinen, 1942; Sheth \& Rao, 1962), dog (Bartlett, 1958, 1962; Wales \& White, 
1964) and fowl (Lake, Butler, McCallum \& MacIntyre, 1958). Cragle, Salisbury \& VanDemark (1958) determined the distribution of sodium, potassium and calcium between the spermatozoa and seminal plasma of bull semen, and Dott \& White (1964) have made preliminary observations on potassium distribution in ram semen.

The authors have developed a technique for the accurate and rapid estimation of sodium, potassium, calcium and magnesium in semen, with an atomic absorption spectrophotometer, and analyses of the semen of the ram, bull, rabbit, man, dog and fowl are presented. A method for the efficient separation of spermatozoa and seminal plasma is also described, and the distribution of the major cations between the spermatozoa and seminal plasma has been determined for each species.

\section{MATERIALS AND METHODS}

Semen was collected from Merino rams with the bipolar electrode of Blackshaw (1954) and a maximum stimulation of 10 volt at $40 \mathrm{cyc} / \mathrm{sec}$. Bull and rabbit semen was collected with an artificial vagina; in the latter species, the apparatus of White (1955) was used. Human, dog and fowl (Burrows \& Quinn, 1939) semen was obtained by massage. Care was taken to prevent cold shock and only samples of good initial motility were used.

The reproductive tracts of Merino rams and Hereford bulls were removed immediately after slaughter and packed in ice for transport to the laboratory. Epididymal semen was collected by making small incisions in the cauda epididymidis and squeezing out the fluid. Ampullae and seminal vesicles were cleaned of surrounding tissue and the fluid squeezed out of the divided ducts.

Specially made $5 \mathrm{ml}$ tapering tubes (inside diameter $3 \mathrm{~mm}$ in the lower portion and $10 \mathrm{~mm}$ in the upper portion) (Text-fig. 1), gave good separations of spermatozoa and plasma when centrifuged $(4000 \mathrm{~g})$ at 15 to $20^{\circ} \mathrm{C}$ for 30 min. The seminal plasma was drawn off for analysis immediately and the small amount of kinoplasmic droplet material on top of the sperm plug discarded. The walls of the tubes were carefully washed with distilled water and dried with low ash filter paper. The spermatozoa were then weighed and resuspended in a convenient volume of distilled water.

Samples were diluted in distilled water for sodium estimations and in special 'swamping' solutions for potassium, calcium and magnesium determinations. The 'swamping' solution for potassium estimations gave a final concentration of $200 \mathrm{ppm}$ of sodium, and the 'swamping' solution for calcium and magnesium gave a final concentration of $1500 \mathrm{ppm}$ of strontium, 1500 $\mathrm{ppm}$ of potassium and $200 \mathrm{ppm}$ of sodium. Strontium prevents calcium and magnesium from forming compounds with interfering anions, and an excess of sodium and potassium was added to 'swamp' any of these ions in the samples. Standards containing 0.5 to $5.0 \mathrm{ppm}$ of sodium, potassium or calcium and 0.1 to $1.0 \mathrm{ppm}$ of magnesium were run with the unknown samples. The chloride salts of each cation were used to prepare all solutions and the standards contained the same concentration of 'swamping' constituents as the unknown samples. Varying the final concentration of 'swamping' 
constituents from one-half to four times did not greatly affect the estimation of magnesium and calcium. The final concentration of 'swamping' sodium is, however, critical in the determination of potassium. In preliminary experiments, semen was ashed in silicon crucibles at $450^{\circ} \mathrm{C}$ for at least $4 \mathrm{hr}$, full digestion being ensured by adding $6 \mathrm{~N}-\mathrm{HCl}$.

Sodium, potassium, magnesium and calcium were then estimated by the atomic absorption spectrophotometer described by Willis (1960a, b) and David (1960).

The statistical significance of the results has been assessed by the $t$-test. Where more than two groups have been compared, an analysis of variance has been done, using the sILLIAC electronic computer, and the interaction mean square used to calculate the standard error for the $t$-test.

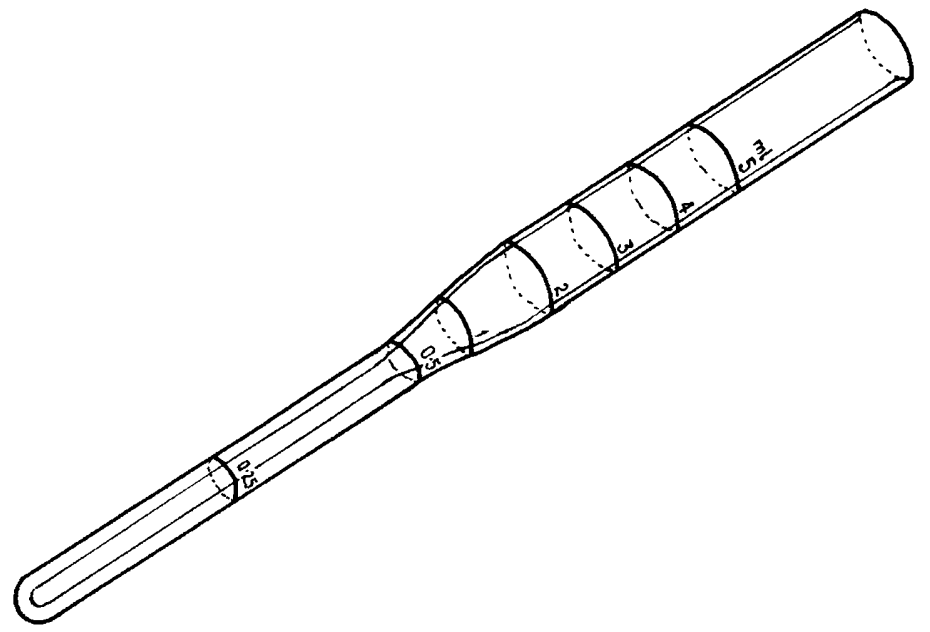

TexT-FIG. 1. Tapered centrifuge tube used for the separation of spermatozoa from seminal plasma.

\section{RESULTS}

\section{Effect of ashing}

The first experiment was designed to check if the organic components of semen had any influence on the estimation of sodium, potassium, calcium and magnesium. Ram and bull semen, spermatozoa and seminal plasma were analysed after ashing, and the results compared with aliquots of the same samples diluted directly in the appropriate 'swamping' solution. Table 1 shows that there was no statistically significant difference between the ashed and unashed samples, and in subsequent experiments the ashing procedure was omitted.

\section{Values for whole semen}

The results of a number of analyses of the cation concentration in the whole semen of the ram, bull, human, rabbit, fowl and dog (sperm-rich fraction) are summarized in Table 2. Sodium (347 to $192 \mathrm{mg} / 100 \mathrm{~g}$ ) and potassium ( 142 to $35 \mathrm{mg} / 100 \mathrm{~g}$ ) are the predominant cations in the semen of the 
six species studied, with lower concentrations of calcium ( 44 to $1 \mathrm{mg} / 100 \mathrm{~g}$ ) and magnesium (25 to $2 \mathrm{mg} / 100 \mathrm{~g}$ ). The sodium:potassium ratio is greater than 1:0.6 in all species, and in the dog is as high as $1: 0 \cdot 1$. The ratio of calcium to magnesium varies from $1: 0 \cdot 2$ in the bull to $1: 3.2$ in the rabbit.

Bull semen is noteworthy for its high potassium and calcium content and rabbit semen for its high magnesium. The sperm-rich fraction from the dog is characterized by a low concentration of potassium, calcium and magnesium.

TABLE 1

EFFEGT OF ASHING ON THE DETERMINATION OF GATIONS IN SEMEN

\begin{tabular}{|c|c|c|c|c|}
\hline Method & Sodium & Potassium & Calcium & Magnesium \\
\hline $\begin{array}{l}\text { Ashed } \\
\text { Unashed }\end{array}$ & $\begin{array}{l}164 \pm 12 \cdot 9 \\
164 \pm 12 \cdot 1\end{array}$ & $\begin{array}{l}98 \pm 6 \cdot 9 \\
99 \pm 6 \cdot 3\end{array}$ & $\begin{array}{r}10 \cdot 6 \pm 1 \cdot 05 \\
9.6 \pm 0.83\end{array}$ & $\begin{array}{l}8.9 \pm 0.71 \\
8 \cdot 0 \pm 0.57\end{array}$ \\
\hline
\end{tabular}

Mean values $(\mathrm{mg} / 100 \mathrm{~g}) \pm$ S.E. are given for nineteen samples of ram and bull whole semen (seven), spermatozoa (six) and seminal plasma (six).

TABLE 2

CONGENTRATION OF MAJOR GATIONS IN THE WHOLE SEMEN OF VARIOUS SPECIES

\begin{tabular}{l|c|r|r|r}
\hline \multicolumn{1}{c|}{ Species } & Sodium & \multicolumn{1}{c|}{ Potassium } & \multicolumn{1}{c|}{ Calcium } & \multicolumn{1}{c}{ Magnesium } \\
\hline Ram (10) & $192 \pm 9 \cdot 8$ & $92 \pm 8 \cdot 7$ & $10 \cdot 6 \pm 1 \cdot 02$ & $7 \cdot 8 \pm 0 \cdot 98$ \\
Bull (10) & $233 \pm 15 \cdot 7$ & $142 \pm 12 \cdot 0$ & $44 \cdot 1 \pm 2 \cdot 55$ & $8 \cdot 8 \pm 0 \cdot 18$ \\
Human (10) & $308 \pm 9 \cdot 2$ & $88 \pm 5 \cdot 2$ & $20 \cdot 6 \pm 1 \cdot 65$ & $6 \cdot 5 \pm 1 \cdot 32$ \\
Dog* (9) & $315 \pm 10 \cdot 6$ & $35 \pm 3 \cdot 5$ & $0 \cdot 8 \pm 0 \cdot 26$ & $1 \cdot 8 \pm 0.02$ \\
Rabbit (6) & $205 \pm 14 \cdot 1$ & $75 \pm 7 \cdot 6$ & $8 \cdot 0 \pm 1 \cdot 63$ & $25 \cdot 2 \pm 3.44$ \\
Fowl (15) & $347 \pm 12 \cdot 2$ & $57 \pm 4 \cdot 2$ & $10 \cdot 4 \pm 1 \cdot 39$ & $8 \cdot 2 \pm 1 \cdot 22$ \\
\hline
\end{tabular}

Mean values $(\mathrm{mg} / 100 \mathrm{~g}) \pm$ S.E. are given with the number of replicates in parentheses.

* Sperm-rich fraction.

\section{Distribution of cations between spermatozoa and plasma}

The distribution of the major cations between spermatozoa and seminal plasma of the various species is summarized in Table 3. Analyses of prostatic fluid from the dog, which was collected separately from the sperm-rich fraction, have also been included.

In all species, the concentration of sodium was significantly less in the spermatozoa than in the seminal plasma, whilst the reverse was true for potassium, i.e. the concentration of potassium was significantly greater in the spermatozoa than in the seminal plasma.

There was no evidence of a similar reciprocal distribution of the divalent ions, magnesium and calcium. The magnesium concentration of the spermatozoa always exceeded that of the plasma, whilst the same was true for calcium, except in the bull where the concentration of calcium in the plasma exceeded that in the spermatozoa. There is a marked similarity between the cation composition of dog seminal plasma and prostatic fluid, which both have a 
high sodium concentration and a low content of potassium, calcium and magnesium.

Since it was often necessary to pool ejaculates for experiments, the effect of pooling bull semen on the cation distribution between the spermatozoa and plasma was checked. First and second ejaculates were pooled and the cation

TABLE 3

DISTRIBUTION OF GATIONS BETWEEN SPERMATOZOA AND SEMINAL PLASMA

\begin{tabular}{|c|c|c|c|c|c|}
\hline Species & Material & Sodium & Potassium & Calcium & Magnesium \\
\hline $\operatorname{Ram}(21)$ & $\begin{array}{l}\text { Spermatozoa } \\
\text { Plasma }\end{array}$ & $\begin{array}{l}111 \pm 6 \cdot 3 \\
178 \pm 11 \cdot 1 * *\end{array}$ & $\begin{aligned} & 132 \pm 5 \cdot 3 \\
& 89 \pm 3 \cdot 6^{* *}\end{aligned}$ & $\begin{array}{l}6 \cdot 4 \pm 2 \cdot 5 \\
6 \cdot 3 \pm 1 \cdot 9\end{array}$ & $\begin{array}{r}13 \cdot 3 \pm 1 \cdot 8 \\
5 \cdot 8 \pm 0 \cdot 8 * *\end{array}$ \\
\hline Bull (20) & $\begin{array}{l}\text { Spermatozoa } \\
\text { Plasma }\end{array}$ & $\begin{array}{l}150 \pm 9 \cdot 3 \\
225 \pm 12 \cdot 9 * *\end{array}$ & $\begin{array}{l}194 \pm 15 \cdot 3 \\
155 \pm 6 \cdot 4 * *\end{array}$ & $\begin{array}{l}27 \cdot 2 \pm 1 \cdot 8 \\
39 \cdot 6 \pm 1 \cdot 7 * *\end{array}$ & $\begin{array}{l}13 \cdot 8 \pm 0 \cdot 86 \\
8 \cdot 1 \pm 0 \cdot 25 * *\end{array}$ \\
\hline Human (11) & $\begin{array}{l}\text { Spermatozoa } \\
\text { Plasma }\end{array}$ & $\begin{array}{l}202 \pm 9 \cdot 6 \\
258 \pm 9 \cdot 2 * *\end{array}$ & $\begin{array}{c}171 \pm 31 \cdot 3 \\
91 \pm 10 \cdot 9 * *\end{array}$ & $\begin{array}{l}35 \cdot 2 \pm 2 \cdot 7 \\
28 \cdot 2 \pm 3 \cdot 3\end{array}$ & $\begin{array}{c}15 \cdot 3 \pm 1 \cdot 8 \\
9 \cdot 0 \pm 1 \cdot 2 * *\end{array}$ \\
\hline $\operatorname{Dog}(7)$ & $\begin{array}{l}\text { Spermatozoa } \dagger \\
\text { Plasma } \dagger \\
\text { Prostatic fluid }\end{array}$ & $\begin{array}{l}288 \pm 50 \cdot 8 \\
332 \pm 10 \cdot 7^{* *} \\
355 \pm 9 \cdot 9^{* *}\end{array}$ & $\begin{array}{l}125 \pm 14 \cdot 6 \\
31 \pm 4 \cdot 4^{* *} \\
34 \pm 2 \cdot 9^{* *}\end{array}$ & $\begin{array}{c}13 \cdot 1 \pm 1 \cdot 44 \\
4 \cdot 8 \pm 0.51^{* *} \\
4 \cdot 4 \pm 0.64^{* *}\end{array}$ & $\begin{array}{l}17 \cdot 1 \pm 1.49 \\
3.7 \pm 0.99^{* *} \\
1.5 \pm 0.46^{* *}\end{array}$ \\
\hline Rabbit (5) & $\begin{array}{l}\text { Spermatozoa } \\
\text { Plasma }\end{array}$ & $\begin{array}{l}113 \pm 5 \cdot 5 \\
142 \pm 9 \cdot 0^{* *}\end{array}$ & $\begin{array}{l}97 \pm 7 \cdot 9 \\
77 \pm 5 \cdot 0^{* *}\end{array}$ & $\begin{array}{l}25 \cdot 8 \pm 4 \cdot 5 \\
6 \cdot 1 \pm 1 \cdot 2^{* *}\end{array}$ & $\begin{array}{l}31 \cdot 6 \pm 3 \cdot 9 \\
26 \cdot 3 \pm 2 \cdot 3\end{array}$ \\
\hline Fowl (8) & $\begin{array}{l}\text { Spermatozoa } \\
\text { Plasma }\end{array}$ & $\begin{array}{l}335 \pm 44 \cdot 4 \\
420 \pm 17 \cdot 0 * *\end{array}$ & $\begin{array}{l}166 \pm 39 \cdot 8 \\
32 \pm 3 \cdot 4 * *\end{array}$ & $\begin{array}{r}18 \cdot 0 \pm 5 \cdot 01 \\
8 \cdot 7 \pm 1 \cdot 01\end{array}$ & $\begin{array}{c}18 \cdot 3 \pm 2 \cdot 44 \\
6 \cdot 2 \pm 1 \cdot 12 * *\end{array}$ \\
\hline
\end{tabular}

Means values $(\mathrm{mg} / 100 \mathrm{~g}) \pm$ S.E. are given with the number of replicates in parentheses.

+ Obtained from the sperm-rich fraction.

* Significantly different from spermatozoa, $P<0.05$.

** Significantly different from spermatozoa, $P<0.01$.

TABLE 4

CORRELATION GOEFFICIENTS BETWEEN SODIUM AND POTASSIUM IN SPERMATOZOA AND SEMINAL PLASMA

\begin{tabular}{l|l|l|l|l|l|l}
\hline \multicolumn{1}{c|}{ Correlation } & Ram (19) & Bull (18) & Man (12) & Dog (14) & Rabbit (9) & Fowl (18) \\
\hline $\mathrm{Na}^{+}: \mathrm{K}^{+}$in spermatozoa & +0.245 & +0.259 & -0.021 & -0.253 & +0.546 & +0.020 \\
$\mathrm{Na}^{+}: \mathrm{K}^{+}$in plasma & $+0.510^{*}$ & $-0.509^{*}$ & +0.278 & -0.237 & $-0.884^{* * *}$ & -0.278 \\
$\mathrm{Na}^{+}$in spermatozoa : & $+0.577^{* *}$ & +0.432 & +0.002 & +0.236 & +0.220 & +0.180 \\
$\quad \mathrm{Na}^{+}$in plasma \\
$\begin{array}{l}\mathrm{K}^{+} \text {in spermatozoa : } \\
\mathrm{K}^{+} \text {in plasma }\end{array}$ & $+0.435^{*}$ & $+0.803^{* *}$ & $+0.537^{*}$ & +0.364 & +0.554 & +0.089 \\
\hline
\end{tabular}

The number of observations are given in parentheses.

$$
\text { * } P<0.05 ; \quad * * P<0.01 \text {. }
$$

concentrations were compared with an estimated value calculated from analyses of the individual ejaculates before pooling. Except for a slight rise in plasma magnesium concentration, no significant differences were observed.

The correlation coefficients between sodium and potassium, for the spermatozoa and seminal plasma of the various species, are shown in Table 4. There is a significant positive correlation between sodium and potassium for the plasma of the ram, but negative ones in the bull and rabbit. The sodium concentration of the spermatozoa and plasma are positively correlated in the ram and the same is true for potassium in the ram, bull and man. 
Effect of time on distribution of cations

The possibility of changes in the distribution of cations in bull, human and dog semen after ejaculation was investigated by separating the spermatozoa from the plasma immediately after ejaculation and after the semen had been incubated at 20 to $25^{\circ} \mathrm{C}$ for $5 \mathrm{hr}$. However, except for a slight fall in the magnesium concentration (mean $14.5 \mathrm{mg} / 100 \mathrm{~g}$ to $11.5 \mathrm{mg} / 100 \mathrm{~g}$ for six ejaculates, $P<0.05$ ) of bull spermatozoa, no significant changes in the distribution of the cations was observed. There was little decline in motility and $\mathrm{pH}$ during this period.

\section{Cations in epididymal, vesicular and ampullar fuid}

Seven rams were ejaculated and the distribution of cations determined in their semen; the following day the animals were slaughtered and analysis made on their epididymal semen and vesicular fluid. The results (Table 5) and analysis of variance (Table 6) show significant differences between the concentration of cations in ejaculated and epididymal semen and also between semen fractions.

TABLE 5

DISTRIBUTION OF MAJOR CATIONS IN EJACULATED RAM SEMEN AND REPRODUGTIVE TRAGT FLUIDS OF THE SAME RAMS

\begin{tabular}{|c|c|c|c|c|c|}
\hline Source & Fraction & Sodium & Potassium & Calcium & Magnesium \\
\hline Ejaculate & $\begin{array}{l}\text { Whole semen } \\
\text { Spermatozoa } \\
\text { Plasma } \\
\text { Pre-spermatozoa }\end{array}$ & $\begin{array}{l}203 \pm 19 \cdot 4 \\
117 \pm 9 \cdot 9 \\
212 \pm 12 \cdot 7 \\
281 \pm 11 \cdot 1\end{array}$ & $\begin{array}{r}85 \pm 8 \cdot 9 \\
130 \pm 7 \cdot 1 \\
67 \pm 9 \cdot 4 \\
100 \pm 18 \cdot 7\end{array}$ & $\begin{array}{r}8 \cdot 2 \pm 1 \cdot 22 \\
10 \cdot 6 \pm 2 \cdot 11 \\
7 \cdot 6 \pm 1 \cdot 17 \\
9 \cdot 1 \pm 0 \cdot 77\end{array}$ & $\begin{array}{r}6 \cdot 8 \pm 0.64 \\
14 \cdot 8 \pm 0 \cdot 91 \\
4 \cdot 9 \pm 0 \cdot 33 \\
4 \cdot 1 \pm 1.02\end{array}$ \\
\hline Epididymis & $\begin{array}{l}\text { Whole semen } \\
\text { Spermatozoa } \\
\text { Plasma }\end{array}$ & $\begin{array}{r}59 \pm 7 \cdot 9 \\
49 \pm 4 \cdot 7 \\
92 \pm 10 \cdot 9\end{array}$ & $\begin{array}{r}120 \pm 5 \cdot 1 \\
247 \pm 7 \cdot 5 \\
94 \pm 3 \cdot 9\end{array}$ & $\begin{array}{l}4 \cdot 8 \pm 1 \cdot 22 \\
7 \cdot 1 \pm 2 \cdot 32 \\
3 \cdot 8 \pm 1 \cdot 03\end{array}$ & $\begin{array}{r}12 \cdot 9 \pm 0 \cdot 31 \\
20 \cdot 3 \pm 0 \cdot 85 \\
3 \cdot 1 \pm 0 \cdot 39\end{array}$ \\
\hline Seminal vesicles & Fluid & $215 \pm 9.9$ & $143 \pm 10 \cdot 5$ & $13 \cdot 6 \pm 1 \cdot 49$ & $7 \cdot 7 \pm 0.53$ \\
\hline
\end{tabular}

Mean values $(\mathrm{mg} / 100 \mathrm{~g}) \pm$ S.E. are given for seven rams.

Perhaps the most striking difference, as far as the whole semen is concerned, is the much lower sodium concentration of epididymal semen due to both the epididymal plasma and spermatozoa having only half the sodium concentrations of the corresponding ejaculated fractions. Another noteworthy difference is the very high potassium concentration of epididymal spermatozoa, which is almost double the value for ejaculated spermatozoa. This means that the ratio of potassium to sodium is $5: 1$ in the epididymal spermatozoa of the ram compared to $1: 1$ in the ejaculated cells. The pattern of distribution of cations between spermatozoa and plasma is, however, similar for ram epididymal and ejaculated semen, i.e. the potassium, calcium and magnesium content of the cells exceeds the plasma whilst the reverse is true for sodium. This pattern is also found in the epididymal semen of the bull (Table 7) which differs from the ejaculated semen of this species in its lower concentration of sodium and the fact that the spermatozoa contain more calcium than the 
plasma. Like the seminal plasma of the bull, both the vesicular fluid and ampullar lumen fluid contain very high concentrations of calcium.

\section{TABLE 6}

ANALYSIS OF VARIANCE FOR THE SPERMATOZOA, SEMINAL PLASMA AND WHOLE SEMEN VALUES IN TABLE 5

\begin{tabular}{l|r|r|r|r|r}
\hline \multirow{2}{*}{ Source of variation } & \multirow{2}{*}{ d.f. } & \multicolumn{5}{|c}{ Variance ratios } \\
\cline { 5 - 6 } & & Sodium & Potassium & Calcium & Magnesium \\
\hline Between replicates (R) & 6 & $4 \cdot 16^{*}$ & $5 \cdot 10^{* *}$ & $10 \cdot 26^{* *}$ & $1 \cdot 97$ \\
Between ejaculated and & & & & & \\
$\quad$ epididymal (S) & 1 & $316 \cdot 19^{* *}$ & $483 \cdot 07^{* *}$ & $18 \cdot 82^{* *}$ & $40 \cdot 83^{* *}$ \\
Between fractions (F) & 2 & $43 \cdot 65^{* *}$ & $586 \cdot 85^{* *}$ & $5 \cdot 27^{*}$ & $233 \cdot 10^{* *}$ \\
Interactions & 6 & $6 \cdot 23^{* *}$ & $1 \cdot 63$ & $1 \cdot 21$ & $0 \cdot 24$ \\
$\mathrm{R} \times \mathrm{S}$ & 12 & $1 \cdot 01$ & $1 \cdot 94$ & $0 \cdot 57$ & $0 \cdot 82$ \\
$\mathrm{R} \times \mathrm{F}$ & 2 & $12 \cdot 80^{* *}$ & $110 \cdot 50^{* *}$ & $0 \cdot 02$ & $23 \cdot 80^{* *}$ \\
$\mathrm{~S} \times \mathrm{F}$ & 12 & $407 \cdot 75$ & $78 \cdot 73$ & $7 \cdot 23$ & $2 \cdot 77$ \\
$\mathrm{R} \times \mathrm{S} \times \mathrm{F}$ (residual) & & & & & \\
\hline
\end{tabular}

The error mean square is given in italics at the base of the variance ratio columns.

$* P<0.05 ; \quad * * P<0.01$.

TABLE 7

DISTRIBUTION OF MAJOR CATIONS IN REPRODUCTIVE TRACT FLUIDS OF THE BULL

\begin{tabular}{l|c|c|c|c|c}
\hline \multicolumn{1}{c|}{ Fluid } & Fraction & Sodium & Potassium & Calcium & Magnesium \\
\cline { 2 - 4 } Epididymal semen & Spermatozoa & $48 \pm 3 \cdot 6$ & $141 \pm 3 \cdot 7$ & $15 \cdot 9 \pm 2 \cdot 35$ & $16 \cdot 5 \pm 0 \cdot 32$ \\
& Plasma & $87 \pm 14 \cdot 8 * *$ & $84 \pm 3 \cdot 2 * *$ & $9 \cdot 2 \pm 0 \cdot 34 *$ & $3 \cdot 0 \pm 0 \cdot 43^{* *}$ \\
Seminal vesicle fluid & - & $249 \pm 18 \cdot 8$ & $106 \pm 13 \cdot 8$ & $50 \cdot 2 \pm 4 \cdot 05$ & $9 \cdot 4 \pm 0 \cdot 88$ \\
Ampullar lumen fluid & Whole & $249 \pm 20 \cdot 1$ & $109 \pm 13 \cdot 3$ & $38 \cdot 4 \pm 3 \cdot 33$ & $6 \cdot 6 \pm 0 \cdot 35$ \\
\hline
\end{tabular}

Mean values $(\mathrm{mg} / 100 \mathrm{~g}) \pm$ S.E. are given for six replicates.

* Significantly different from spermatozoa, $P<0.05$.

** Significantly different from spermatozoa, $P<0.01$.

\section{DISCUSSION}

The atomic absorption spectrophotometer provides a simple and easy method of determining sodium, potassium, calcium and magnesium in whole semen and in the spermatozoa and seminal plasma, which can be conveniently separated in the special tapering tubes described.

Willis $(1960 \mathrm{a}, \mathrm{b})$ has shown that the estimation of calcium and magnesium in blood serum by atomic absorption spectrophotometry is influenced by the organic components of the serum and he advocates the addition of strontium to overcome the influence on the estimation of magnesium. The presence of $1500 \mathrm{ppm}$ of strontium must overcome any such interference in the analysis of unashed semen and clearly there is no need to ash samples for sodium, potassium, calcium or magnesium analyses if they are diluted in the appropriate 'swamping' solution. We have not encountered the difficulties experienced by Rothschild \& Barnes (1954) in the estimation of sodium in bovine seminal plasma by flame photometry. These authors report variable results for sodium despite reliable figures being obtained when measuring potassium. 
The sodium, potassium and calcium ion concentrations found in whole bull semen agree with those of Rothschild \& Barnes (1954), Cragle, Salisbury \& Muntz (1958) and Cragle, Salisbury \& VanDemark (1958) and are at variance with Bernstein (1933), who reported that the potassium concentration greatly exceeds sodium. Fewer data on ram semen are available for comparison, but our sodium and magnesium values are about twice those reported by Mann (1964) and are more in line with those of the other species studied. The potassium values are similar to those previously published by Dott \& White (1964) for Suffolk rams. Analyses of fowl, human and dog semen agree with those published by Lake, Butler, McCallum \& MacIntyre (1958), Huggins, Scott \& Heinen (1942) and Bartlett (1962), respectively. There are apparently no data in the literature on the cation content of rabbit semen.

When the concentrations of the major cations in whole semen are compared with those in the whole blood of a particular species (Quinn \& White, unpublished data) the ratio is found to vary greatly with the species. However, in all the species studied, spermatozoa had a higher calcium and magnesium concentration than the erythrocytes, and seminal plasma contained more potassium and magnesium than the respective blood plasma.

The reciprocal relation of potassium to sodium in the spermatozoa and seminal plasma (i.e. high potassium and low sodium in spermatozoa; low potassium and high sodium in the seminal plasma) was first reported by Cragle, Salisbury \& Muntz (1958) for the bull, and by Dott \& White (1964) for the ram. The present studies show that this is a general occurrence and the ratio is not reversed in human semen as suggested by Sheth \& Rao (1962); the effect is most marked in the dog and fowl.

Attention has been drawn to the inverse relationship between sodium and potassium in the seminal plasma of the bull (Rothschild \& Barnes, 1954; Cragle et al., 1958). We have confirmed this (Table 4) and found that it also occurs in the rabbit. In the ram, however, the relationship is a direct one. One might conclude that the inverse relationship between sodium and potassium in seminal plasma is not of great physiological significance, or that the mechanism controlling the normal cation contribution of accessory organs to the ejaculate has been disturbed by the electrical stimulation of the ram.

Calcium and magnesium concentrations in spermatozoa resemble that of potassium in that the spermatozoa tend to contain more per unit weight than the seminal plasma. The bull is a notable exception, however, as in this species the calcium concentration of the seminal plasma not only exceeds that in the spermatozoa, but is also much higher than in the blood. The bulk of the calcium clearly comes from the seminal vesicles and ampullae. Extremely high calcium values (up to $66 \mathrm{mg} / 100 \mathrm{~g}$ ) have on occasions been found in rabbit semen, due, probably, to the presence of calcium carbonate crystals (Quinn \& White, unpublished observations).

The distribution of sodium and potassium between the spermatozoa and seminal plasma suggests the operation of a sodium pump mechanism in spermatozoa similar to that shown to occur in human and rabbit erythrocytes (Glynn, 1956; Rummel, Pfleger \& Seifen, 1961). However, the gradients of these cations in semen are not as great as exist between the erythrocytes and 
blood plasma of most species (Quinn \& White, unpublished data). Furthermore, we have found no significant changes in the distribution of sodium and potassium after incubation of bull, human and dog semen for $5 \mathrm{hr}$. Herman \& Swanson (1941) report that the motility of undiluted bull semen was good after $6 \mathrm{hr}$ at 21 to $24^{\circ} \mathrm{C}$, but decreased greatly after $16 \mathrm{hr}$; a longer period of incubation than $5 \mathrm{hr}$ may, therefore, be necessary to demonstrate a disturbance of ionic distribution between the spermatozoa and seminal plasma.

Although the pattern of distribution of cations between the spermatozoa and seminal plasma is, in general, similar for epididymal and ejaculated semen, there are substantial shifts in absolute concentration, as both spermatozoa and plasma pass from the epididymis and are ejaculated. Due to the contribution of the seminal vesicles, the sodium concentration of ram and bull spermatozoa is about doubled, whilst, in the ram, the potassium content of the spermatozoa is halved. Another noteworthy example is the high concentration of calcium to which bull and, to a lesser extent, ram spermatozoa are exposed on admixture with vesicular fluid.

The values obtained for the sodium and potassium concentration of epididymal plasma are in agreement with those of Sørensen \& Andersen (1956), Scott, Wales, Wallace \& White (1963) and Grabo \& Gustafsson (1964), and confirm a 1:1 ratio of these cations in the bull and ram. We have also confirmed the high sodium and calcium content of bull vesicular secretion (Cragle, Salisbury \& Muntz, 1958) but find that the potassium content is much lower than reported by Salisbury \& Cragle (1956).

\section{ACKNOWLEDGMENTS}

The authors are indebted to Professor G. W. Emmens for his interest and advice. We are grateful to Mr P. Bryden of the N.S.W. State Abattoirs, Homebush, for his co-operation in obtaining genital tracts from bulls, to $\mathrm{Dr} \mathrm{H}$. W. McNary of the Poultry Research Unit, Camden, for the supply of fowl semen, and to the Sterility Clinic, Women's Hospital, Crown Street, Sydney, for human semen. The work was aided by grants from the Ford Foundation, the Rural Credits Development Fund of the Commonwealth Bank of Australia, the Wool Research Trust and the Dairy Produce Research Trust Account.

\section{REFERENCES}

Bartlett, D. J. (1958) Biochemical characteristics of dog semen. Nature, Lond. 182, 1605.

BartletT, D. J. (1962) Studies on dog semen. II. Biochemical characteristics. 7. Reprod. Fertil. 3, 190. Bernstein, A. (1933) Ob obmene gljukozy v sperme. Etjudy po fiziologii spermatozoidov. Trans. vet. Path., Orenburg vet. Inst. No. 1, p. 9; Abstract in Anim. Breed. Abstr. (1935) 3, 478.

Blackshaw, A. W. (1953a) The effects of potassium and calcium salts on the motility of ram, rabbit and bull spermatozoa. F. Physiol. 120, 465.

Blackshaw, A. W. (1953b) The motility of ram and bull spermatozoa in dilute suspension. $\mathcal{J}$. gen. Physiol. 36, 449.

Blackshaw, A. W. (1954) A bipolar rectal electrode for the electrical production of ejaculation in sheep. Aust. vet. $7.30,249$.

Burrows, W. H. \& Quins, J. P. (1939) Artificial insemination of chickens and turkeys. Dep. Circ. U.S. Dep. Agric. No. 525 .

Crabo, B. \& Gustafsson, B. (1964) Distribution of sodium and potassium and its relation to sperm concentration in the epididymal plasma of the bull. 7. Reprod. Fertil. 7, 337. 
Cragle, R. G. \& Salisbury, G. W. (1957) Effects of pH, osmotic pressure, and bulk cations on the metabolic activity of bull sperm. F. Dairy Sci. 40,621.

Cragle, R. G. \& Salisbury, G. W. (1959) Factors influencing metabolic activity of bull spermatozoa. IV. $\mathrm{pH}$, osmotic pressure, and the cations, sodium, potassium, and calcium. 7. Dairy Sci. 42, 1304.

Gragle, R. G., Salisbury, G. W. \& Muntz, T. H. (1958) Distribution of bulk and trace minerals in bull reproductive tract fluids and semen. F. Dairy Sci., 41, 1273.

Gragle, R. G., Salisbury, G. W. \& VanDemark, N. L. (1958) Sodium, potassium, calcium and chloride distribution in bovine semen. F. Dairy Sci., 41, 1267.

David, D. J. (1960) The determination of exchangeable sodium, potassium, calcium and magnesium in soils by atomic-absorption spectrophotometry. Analyst, 85, 495.

Dotr, H. M. \& White, I. G. (1964) Effect of potassium on ram spermatozoa studied by a flow dialysis technique. 7. Reprod. Fertil. 7, 127.

Glynn, I. M. (1956) Sodium and potassium movements in human red cells. F. Physiol. 134, 278.

Herman, E. W. \& Swanson, H. A. (1941) Variations in dairy bull semen with respect to its use in artificial insemination. Res. Bull. Mo. agric. Exp. Sta. No. 326, 82.

Huggins, C. B., Scott, W. W. \& Heinen, J. H. (1942) Chemical composition of human semen and of the secretions of the prostate and seminal vesicles. Amer. F. Physiol. 136, 467.

Lake, P. E., Butrler, E. J., McCallum, J. W. \& MacIntyre, I. J. (1958) A chemical analysis of the seminal and blood plasmas of the cock. Quart. 7. exp. Physiol. 43, 309.

LARdy, H. A. \& PhIllips, P. H. (1943) Effect of $\mathrm{pH}$ and certain electrolytes on the metabolism of ejaculated spermatozoa. Amer. 7. Physiol. 138, 741.

MANN, T. (1964) The biochemistry of semen and of the male reproductive tract, 2 nd edn., p. 101. Methuen, London.

Rothschild, LoRd \& Barnes, H. (1954) Constituents of bull seminal plasma. f. exp. Biol., $31,561$.

Rummel, W., Pfleger, K. \& Seifen, E. (1961) Experimental examination of the hypothesis of coupling between the sodium and potassium pump in erythrocytes. $\mathcal{F}$. theoret. Biol. $1,318$.

Salisbury, G. W. \& Gragle, R. G. (1956) Freezing point depressions and mineral levels of fluids of the ruminant male reproductive tract. Proc. IIIrd int. Congr. Anim. Reprod., Cambridge, 1, 25.

Scott, T. W., Wales, R. G., Wallace, J. G. \& White, I. G. (1963) Composition of ram epididymal and testicular fluid and the biosynthesis of glycerylphosphorylcholine by the rabbit epididymis. 7. Reprod. Fertil. 6, 49.

Sheth, A. R. \& RAo, S. S. (1962) Potassium levels in human semen with reference to sperm motility. Experientia, 18, 324.

Sørensen, E. \& Andersen, S. (1956) The influence of sodium and potassium ions upon the motility of sperm cells. Proc. IIIrd int. Congr. Anim. Reprod., Cambridge, 1, 45.

Wales, R. G. \& Whrte, I. G. (1958a) The effect of alkali metal, magnesium, and calcium ions on the motility of fowl spermatozoa. Aust. 7. biol. Sci. 11, 589 .

WALES, R. G. \& WHITE, I. G. (1958b) The effect of the alkali metals, magnesium and calcium on dog spermatozoa. F. Physiol. 142, 494.

Wales, R. G. \& White, I. G. (1964) Some observations on the chemistry of dog semen. 7. Reprod. Fertil. 9, 69.

WALlace, J. C. \& WAlEs, R. G. (1964) Effect of ions on the metabolism of ejaculated and epididymal ram spermatozoa. F. Reprod. Fertil. 8, 187.

WhIte, I. G. (1953a) The effect of washing on the motility and metabolism of ram, bull and rabbit spermatozoa. 7. exp. Biol. 30, 200.

WhIт, I. G. (1953b) The effect of potassium on the washing and dilution of mammalian spermatozoa. Aust. F.exp. Biol. med. Sci. 31, 193.

White, I. G. (1953c) Studies on the alkali metal requirements of ram and bull spermatozoa. Aust. $\mathcal{f}$. biol. Sci. $6,716$.

WhrTE, I. G. (1955) The collection of rabbit semen. Aust. J. exp. Biol. med. Sci. 33, 367.

White, I. G. (1956) The effect of some inorganic ions on mammalian spermatozoa. Proc. IIIrd int. Congr. Anim. Reprod., Cambridge, 1, 23.

Willis, J. B. (1960a) The determination of metals in blood serum by atomic absorption spectroscopy. I. Calcium. Spectrochim. Acta, 16, 259.

WiLlis, J. R. (1960b) The determination of metals in blood serum by atomic absorption spectroscopy. II. Magnesium. Spectrochim. Acta, 16, 273. 